\title{
ПРАВОВОЕ ПОЛОЖЕНИЕ ЖЕНЩИН В РУССКОМ ГОСУДАРСТВЕ С Х ВЕКА ДО ПЕРВОЙ ПОЛОВИНЫ ХVII ВЕКА
}

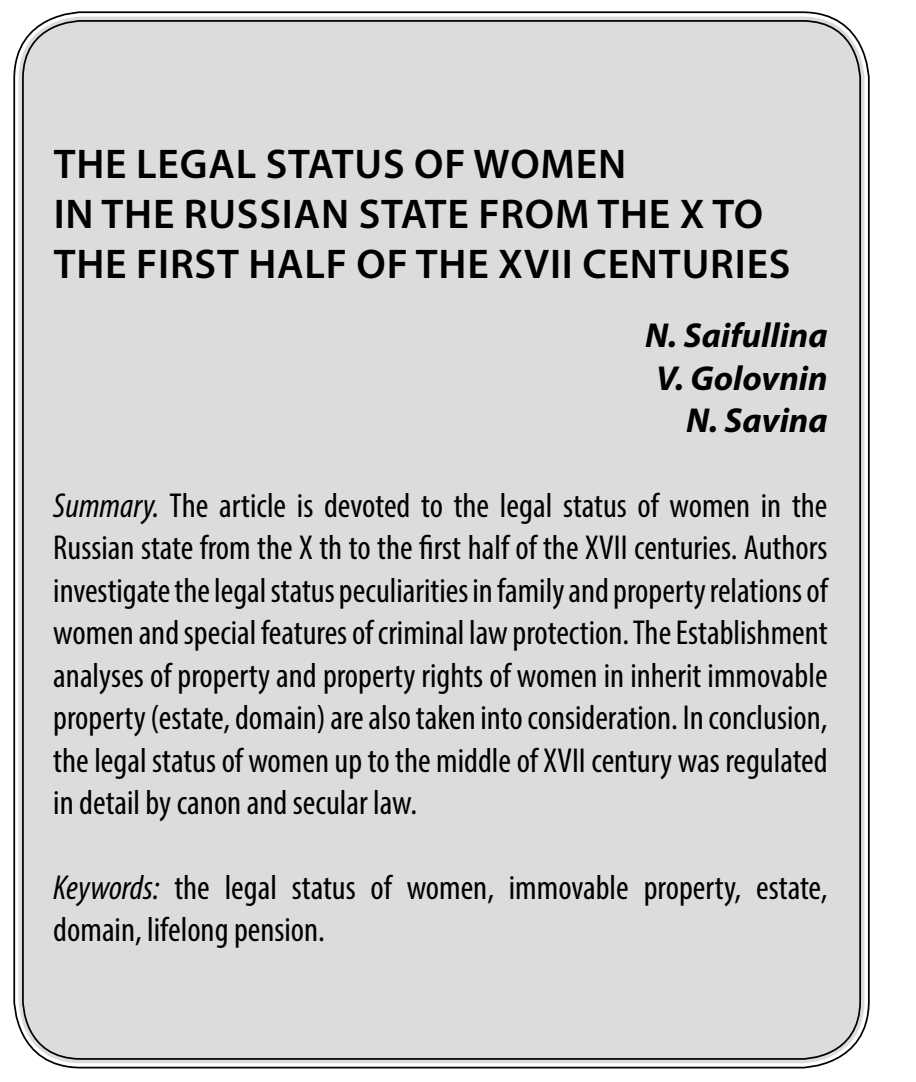

X енщины на протяжении многих столетий, согласно патриархальной концепции, не были полноценными представителями человеческого рода и полностью зависели от воли главы семьи (отца, мужа, сына). Н.И. Костомаров в своих исследованиях характеризовал древнерусскую женщину как существо ниже мужчины [1]. Зависимое и неравноправное положение женщины в семье до XVI века регламентировалось в основном церковными нормами, которые предусматривали многочисленные запреты: не допускалось вступать в брак с представителями другого сословия либо иноверцами, заключать не более двух браков, третий - в виде исключения. В быту она была лишена многих прав: посещать церковь с открытым лицом; ходить в гости без сопровождения супруга; есть, пить, спать вне дома; сидеть, возложив ногу на ногу. Интересен тот факт, что общение жены вне дома с другими мужчинами до XII в. было основанием для развода. Но в тоже время Устав Ярослава Владимировича Краткой редакции «О церковных судах» (середина XIV в.) запрещал разводиться с женой при отсутствии ее вины, в случае ее слепоты либо наличия тяжелой неизлечимой болезни.
Сайфуллина Надежда Алимбаевна

К.ю.н., доцент, Тюменский государственный университет

n.a.sajfullina@utmn.ru

Головнин Владимир Николаевич

К.э.н., доцент, Тюменский государственный университет v.n.golovnin@utmn.ru Савина Наталья Сергеевна Тюменский государственный университет nat-992011@mail.ru

Аннотация. В данной статье анализируется правовое положение женщины в русском государстве с период с X до середины XVII вв. Авторы исследуют особенности правового положения женщины в семейных и имущественных отношениях, а также некоторые особенности уголовно-правовой защиты. Проводят анализ становления собственнических и владельческих прав женщин на недвижимое имущество (вотчины и поместья). Делается вывод o том, что правовое положение женщин до середины XVII века было достаточно подробно урегулировано как каноническим, так и светским правом.

Ключевые слова: правовое положение женщины, недвижимое имущество, вотчина, поместье, «прожиток».

В период централизации русского государства важным литературным источником, регламентировавшим положение женщины в обществе и семье, стал «Домострой» (середина XVI в.), предписывавший мужу «жену свою наказывать и вразумлять наедине страхом». За непослушание мужу разрешалось плетью бить осторожно, разумно и больно. В тоже время «Домострой» запрещал мужу бить жену по уху, по лицу, кулаком под сердце, пинать, колоть, бить железным и деревянным; беременной или роженице не предписывалось кланяться «до пояса». Домострой гласит, что женщина честна только тогда, когда сидит дома и никого не видит. Данный источник регулировал «теремную» (затворническую) жизнь женщин любого сословия до конца исследуемого периода. Но, несмотря на то что правовое положение женщины ограничивали церковные каноны, в исследуемый период происходила постепенная эволюция их имущественных прав. Так, еще в 911 году русско-византийском договором закреплялось право жены на часть имущества[2].

Стоит отметить, что в исследуемый период существовало как движимое, так и недвижимое имущество. Вотчи- 
на как форма феодальной собственности представляла собой родовое имение, принадлежащие членам одного рода. Она появилась в X-XI веке, относилась к недвижимому имуществу, в которое входили земля, постройки, «живой» и «мертвый» инвентарь, и, как правило, находилась в собственности князей и бояр, в отдельных случаях даровалась князем низшим сословиям - приближенным дружинникам. К движимому имуществу относились: домашняя утварь, одежда, украшения, продукты и т.п.

Женщины обладали правом владения и распоряжения в основном только движимым имуществом, которое выделялось ее родственниками при замужестве вне зависимости от социального положения семьи[3]. По мнению О.В.Иншакова, это была «особая форма залога возможности ее существования вне хозяйства будущего или бывшего мужа» [4]. В XV веке данное имущество стало именоваться «приданым». В научном обществе нет единого подхода к пониманию юридической природы приданого. Так, по мнению А.И. Загоровского, оно было общим имуществом супругов, а по мнению К.А. Неволеина, Н.Л.Пушкаревой,- личным имуществом жены [5]. Дочери дружинника либо боярина могли наследовать от отца имущество, но только при отсутствии у нее братьев. Дочь смердов таким правом не обладала.

Высокий уровень развития торговли и экономики в Великом Новгороде способствовали активному вовлечению местных женщин в экономическую сферу общественной жизни. Так, тексты новгородских берестяных грамот указывали на то, что они наделялись правом (с разрешения мужа) распоряжаться имуществом семьи, семейными финансами, совершать куплю-продажу продовольствия и скота, а в отдельных случаях могли даже выступать в сделках от имени отца, мужа или свекра[6].

После смерти мужа женщина становилась главой семьи и хранительницей всего имущества. В соответствии со статьей 93 Русской Правды ей предоставлялся выдел - часть имущество умершего супруга. Ученые неоднозначно понимают юридическую природу такого выдела. Так, по мнению Беляева И.Д., Ярмонова Е. Н., вдова приобретала выдел на праве собственности, но Владимирский-Буданов Б.Н., Никольский В. и Чичерин М.Ф. считали, что она получала его на праве пожизненного владения [7]. В личной же собственности у нее оставалось приданое и вещи, подаренные супругом. Вдова могла сама определить наследника своей собственности: им мог быть как сын или дочь, так и родственники либо иные лица.

B XIV-XV вв. женщины постепенно приобретали собственнические и владельческие права на недвижимость. Собственническими правами обладали представительницы привилегированного сословия. В купчих грамотах (начало XIV в.) содержатся сведения о покупке Великими княгинями земельных уделов. Например, «княгиня Иулиания купила у сына «селце Михайловское» [8]; Анна Кучецкая передала Троице-Сергиеву монастырю свои владения за то, что он списывал долг мужа в размере 5 рублей. Знатные женщины также совершали и другие сделки с недвижимостью, как то: дарение, обмен, заклад и залог. Владельческими правами на недвижимость, как правило, обладали женщины низших сословий. Также вдова имела право на пожизненное пользование движимым и недвижимым имуществом умершего супруга («кормля»), но только при отсутствии завещания и если не выйдет повторно замуж[9]. А вот дочери покойного отца на праве собственности наследовали по закону землю при отсутствии у нее братьев (Судебники 1497 (ст. 60) и 1550 (ст. 92) гг.).

В исследуемый период существовали такие формы землевладения, как поместья и вотчины. «Поместье» как форма землевладения, под которой понимался участок казенной или церковной земли, предоставленный в пользование служивому человеку (боярину, дворянину, стряпчему, дьяку, подьячему, придворному служителю и др.) в качестве вознаграждение за государеву службу, появилось в конце XV века. В случае смерти человека, находящегося на государевой службе, поместье возвращалась обратно царю для раздачи другим служивым людям. В середине XVI века царь либо патриарх мог предоставить сыну умершего данное поместье, а в дальнейшем - поместный оклад, при условии уже поступления его на службу. Получив поместье либо поместный оклад, сыновья обязаны были содержать мать и сестер.

Бездетным вдовам и вдовам с дочерьми после смерти мужа (отца) переходила часть поместья без обязанности с нее служить - «прожиток». Обычно он предоставлялся дочерям и вдовам до их смерти, выхода замуж либо пострижения в монахини.

В случае замужества вдовы и (или) дочерей умершего, родственники получали поместье, что вызывало многочисленные судебные тяжбы, поэтому Указ 1618/19 гг. защитил имущественные интересы вдов и дочерей при вступлении в брак, предоставив им право передавать прожиточные поместья своим мужьям. Часто мужья, получив поместье жен, утаивали свои, что строго было запрещено. При обнаружении такого «мошенничества» изымалось поместье жены, а не мужа, что существенно ограничивало ее имущественное положение, поэтому в Статейном списке 1636 года был введен запрет на изъятие прожиточного поместья у жены, с целью защиты ее материальных (имущественных) интересов. Если такой запрет не был нарушен, то поместье жены переходило к мужу и оставалось у него до конца жизни, то есть не переходило к детям от первого брака. Но если поместье 
было небольшим (от 40 до 100 четей), то мать уже при выходе замуж обязана была оставить его несовершеннолетним сыновьям от первого брака.

Вдова иностранца в случае заключения повторного брака с русским беспоместным дворянином или боярином была вправе передать ему свое поместье. Интересен тот факт, что русским вдовам и девицам запрещалась передача поместий мужьям - служивым людям из других городов. В случае отсутствия мужа, сына или брата, женщины вправе были сдавать прожиточные поместья родственникам, которые в свою очередь обязаны были их содержать и обеспечить при вступлении в брак. Однако при невыполнении ими своих обязанностей вдовы и дочери имели право требовать возращения прожиточного поместья.

После окончания Смоленской войны (1632-1634 гг.), в случае если беспоместный дворянин или боярин был «побит» либо «помер» на государевой службе, вдова, дети бояр и дворян получали на «прожиток» выморочное поместье[10].

Размер «прожитка» в XVI - нач. XVII вв. определялся по усмотрению царя. Так, например, в 1612 году Марья Голенищева получила на «прожиток» деревню Фоминское в Костромском уезде с деревнями и пустошью в размере 100 четей с поместья своего умершего супруга. В 1636 году впервые законодательством были определены размеры «прожитка» вдовы и девицы, мужья и отцы которых не имели своих поместных окладов и кормились с поместий своих отцов. Размер такого прожитка зависел от обстоятельств, при которых умер муж либо отец. Если мужчина погиб при исполнении служебных обязанностей, то размер прожиточного поместья, выдаваемой вдове или дочери, был больше, нежели если он умирал дома[11]. Если умерший уже получил поместный оклад, то вдовы и дочери получали уже точную долю поместья, которая также зависела от обстоятельств смерти мужчины. Так, если муж либо отец погибал на службе, то вдове полагалось 20 четей от оклада в 100 четей, дочери - 10 четей; если же мужчина умирал на службе естественной смертью, то вдова получала 15 четей от оклада в 100 четей, дочь - 7,5 четей; если умирал вне службы (дома), то вдове предоставлялось 10 четей от оклада в 100 четей, дочери - 5 четей[12].

Вотчина как форма землевладения представляла собой родовое имение, принадлежавшее членам одного рода, внутри которого она передавалась по наследству. В период централизации Русского государства распоряжение вотчинами было ограничено. Это связано с тем, что Иван IV пытался ослабить боярско-княжескую власть путем введения запрета на отчуждение вотчины (т.е. на продажу, обмен, заклад, залог, дачу в монастырь либо дачу в приданое дочерям в случае смерти). Стоит отметить, что вотчина бездетной вдове могла предоставляться «на прожиток», но если, по мнению царя, она оказывалась слишком великой, то ее часть могла перейти в его собственность.

Согласно Судебнику 1550 года вотчина подразделялась на два вида: «родовые», находившиеся в собственности рода, и «купленные», находившиеся в общей собственности мужа и жены. Примерно в этот же период возник третий вид вотчины - «выслуженная» (вотчины Государского данья), дававшаяся царем за служебные отличия.

Родовая вотчина была собственностью рода, поэтому женщины не имели право ее наследовать в случае смерти мужа[11]. Что касается дочерей, то Указы 23 мая 1628 г. и 1928/29 гг. закрепляли основной принцип: «сестра при брате не наследница». Дочери наследовали вотчину только в случае отсутствия у умершего сыновей.

Выслуженная (жалованная) вотчина - один из видов вотчины, даровавшейся царем в виде жалованных грамот на землю за заслуги на государственной службе. После окончания военных действий (1608-1620 гг.) происходил массовый перевод поместий в выслуженные вотчины людям, находившимся на воинской службе. Получившие вотчину, а также их дети, внуки, правнуки могли отчуждать свое имущество по своему усмотрению. Интересен тот факт, что в Указе 1618/1619 года право на владение выслуженной вотчиной имела и бездетная вдова, которая была вправе продать, заложить, отдать в монастырь имущество, однако в случае повторного замужества эта вотчина переходила в поместный фонд или могла быть передана во владение нового мужа[13].

Согласно статье 7 Статейного списка 1627 года замужние дочери, сестры, внучки, правнучки и племянницы могли наследовать выслуженные вотчины. Жены после смерти супруга таким правом не обладали и могли иметь в своей собственности четверть «живота» (движимого имущества) и приданое.

Стоит отметить, что данный акт приблизил правовой режим родовых и выслуженных вотчин в праве наследования. Теперь выслуженные вотчины, так же как родовые, закреплялись за родом мужа и не наследовались женой. Женщина получала на прожиток вместо выслуженной вотчины поместье умершего супруга, либо при отсутствии у него данной земли ей предоставлялся «прожиток» с иных поместных земель. Однако существовало исключение для матерей и жен умершего, ушедших в монахини до вступления в действие Статейного списка 1627 года. Им оставалась на прожиток выслуженная вотчина, но после их смерти она возвращалась государству. 
На основании Указа Михаила Федоровича, принятого 21 апреля 1631 года, вдовам и дочерям служивых людей восстанавливалось право владения и пользования выслуженными вотчинами, перешедшие к ним до Статейного списка 3 декабря 1627 года. Это было связано с тем, что Статейный список существенно ограничил право владения родовыми и выслуженными вотчинами, вследствие чего возникали многочисленные земельные споры[14]. Примером может служить спорное дело между вдовой Ириной Текутьевой с дочерью-девицей и ее пасынком Дмитрием Текутьевым. Следующий Указ Михаила Федоровича от 5 декабря 1632 года ограничил право вдовы распоряжаться выслуженной вотчиной, которая была отнята до вступления в действие Статейного Списка[15].

Правовой режим купленных вотчин отличался от двух других видов вотчинного землевладения (выслуженной и родовой). Так, в соответствии с Указом 10 марта 1628 года данная вотчина могла быть приданым девушки, если это было прописано в купчей. Наследовалась же купленная вотчина только бездетной вдовой и вдовой с детьми с правом полного распоряжения.

Уголовно-правовая защита женщин зависела от ее положения в обществе. Так, за убийство ремесленницы и кормилицы предусматривалось денежное взыскание в пользу вотчинника земли в размере 12 гривен (ст. 14, 17), а за рабу - 5 гривен (ст. 16). За убийство мужем жены предусматривалась выплата виры в размере 40 гривен (размер был одинаков и при убийстве женой мужа), но если жена была виновна, то выплата была в 2 раза меньше[5].

Уставом князя Ярослава Владимировича «О церковных судах» Пространной редакции (1051-1054 гг.) предусматривались нормы, защищавшие половую неприкосновенность, честь и достоинство женщины. Так, за умыкание девушки (ст. 2) и оскорбление словом чужой женщины (ст. 30) предусматривалось двойное дифференцированное наказание (выплата обидчице, а также митрополиту), зависящее от ее социального положения. Стоит отметить, что изнасилование (ст. 3), кроме денежного штрафа, выплачиваемого обидчице и митрополиту, каралось также казнью. Позднее, в середине XIV в., Уста- вом князя Ярослава Краткой редакции предусматривалось наказание за избиение чужой жены в виде дифференцированного штрафа (ст. 31) [16].

Женщина могла быть истцом в судебном разбирательстве. Псковская Судная грамота (середина XV в.) регламентировала поведение женщины в случае необходимости судебного поединка. Так, в соответствии со статьей 36, если в долговом обязательстве истцом оказывалась женщина, она имела право вместо себя выставить наемного бойца (наймита). Споры между двумя женщинами в соответствии со статьей 119 решались в судебном поединке без наймита, то есть лишались права выставлять на поединок наемных бойцов[9].

Псковская Судная Грамота предусматривает интересный казус о невиновном причинении вреда истцом и приставом в отношении беременной женщины. Если беременная женщина во время обыска или ареста вора лишалась ребенка, то это, в соответствии со статьей 98, не считалось убийством[9].

В 1637 году впервые законодательно закреплялась защита беременных женщин, которым предоставлялась отсрочка смертной казни в шесть недель после рождения ребенка. В обобщенном и сокращенном виде эта норма появилась позднее в Соборном Уложении Алексея Михайловича 1649 года.

Таким образом, проведя анализ источников древнерусского права, можно сделать следующий вывод. Правовое положение женщины до середины XVII века регулировалось как церковными нормами, так и правовыми обычаями. Церковные догмы, основанные на нормах морали и нравственности, показывали специфику отношений к женщине (дочери, жене, матери, вдовы) в семье. Правовые обычаи, предусмотренные Уставами князя Ярослава Владимира и князя Владимира Святославовича, регулировали социально-экономическое положение женщины в обществе, но более детально источники права X - середины XVII вв. регулировали имущественное положение женщины (правовой режим приданого и наследования) и уголовно-правовую защиту.

\section{ЛИТЕРАТУРА}

1. Костомаров Н. И. Очерк домашней жизни и нравов Великорусского народа в XVI и XVII столетиях. СПб: Тип. Карла Вульфа, 1860. 218 с.

2. Радзивиловская летопись: исследование: описание миниатюр. / Российская академия наук. М.: Искусство. 1994. 415 с.

3. Пространная редакция «Суд Ярослава Владимировича. Правда Русьская» // Российское законодательство Х-ХХ веков в 9 томах. Т. 1. М., Изд.: Юрид. Лит., 1984. 432 c.

4. Иншаков 0. В. Отражение эволюции института семьи в Русской правде // Вестник Волгоградского университета Серия 3: Экономика. Экология. № 4. 2016. C. 6-17

5. Загоровский А.И. О разводе по русскому праву. Харьков: Тип. М. Ф. Зильберберга, 1884. 495 с.; Неволин К. А. История российских гражданских законов. Т. 1. М.: Статут; Консультант плюс, 2005; Пушкарева Н. Л. Женщины Древней Руси. М.: Мысль, 1989. 286 с. 
6. Грамота 8 // URL: http://gramoty.ru/birchbark/document/show/novgorod/8/ (дата обращения: 24.02.2020); Грамота 293 // URL: http://gramoty.ru/birchbark/ document/show/novgorod/293/ (дата обращения: 24.02.2020); Грамота 354 // URL: http://gramoty.ru/birchbark/document/show/novgorod/354/ (дата 06ращения: 24.02.2020)

7. Беляев И.Д. 0 наследстве без завещания по древним русским законам до уложения царя Алексея Михайловича. М.: Унив. тип., 1858. 140 с.; Ярмонова Е. Н. Отдельные аспекты наследования по российскому законодательству: прошлое и современность // Бюллетень нотариальной практики. 2008. № 6 (Размещено в СПС «КонсультантПлюс»); Владимирский-Буданов Б. Н. Обзор истории русского права. М.: Издательский дом «Территория будущего», 2005. 800 с.; Никольский В. Н. 0 началах наследования в древнейшем русском праве. М.: Унив. типография, 1859. 410 с.; Чичерин Б. Н. Опыты истории русского права. М.: Тип. Эрнста Барфкиехта. 1858. 402 с.

8. Духовные договорные грамоты великих и удельных князей XIV-XV вв. / Под ред. С. В. Бахрушина. М.; Л.: Издательство АН СССР, 1950.585 с.

9. Псковская судная грамота // Российское законодательство X-XX веков в 9 томах. Т. 1 / Под ред. О. И. Чистякова. М.: Изд.: Юрид. Лит, 1984. 432 с.

10. Указ 19 февряля-21 марта 1634 года «0 даче вдовам и детям дворян и детей боярских, погибших под Смоленском, земель на прожиток, а беспоместным дворянам, участвовавшим в осаде Смоленска, выморочных поместий» // Законодательные акты русского государства второй половины XVI — первой половины XVII века. Тексты / Под ред. Н. Е. Носова. Л.: «Наука», 1986. 265 с.

11. Статейный список 17 декабря 1636 года // Законодательные акты русского государства второй половины XVI — первой половины XVII века. Тексты. / Под ред. Н. Е. Носова. Л.: «Наука», 1986. 265 с.

12. Указ 16 августа 1644 года «0 размере прожиточных поместий дач вдовам и дочерям служивых людей» // Законодательные акты русского государства второй половины XVI — первой половины XVII века. Тексты. / Под ред. Н. Е. Носова. Л.: «Наука», 1986. 265 с.

13. Указ 1618/19 года «0 форме жалованных грамот данные за «московское осадное сиденье». // Законодательные акты русского государства второй половины XVI — первой половины XVII века. Тексты. / Под ред. Н. Е. Носова. Л.: «Наука», 1986. 265 с.

14. Статейный список, содержащий девять указов о наследовании выслуженных и родовых вотчин 3 декабря 1627 года. // Законодательные акты русского государства второй половины XVI — первой половины XVII века. Тексты. / Под ред. Н. Е. Носова. Л.: «Наука», 1986. 265 с.

15. Указ 5 декабря 1632 года «0 возвращении вдовам вотчичей, получивших вотчины за «московское осадное сиденье» и умерших ранее указа 3 декабря 1627 года, вотчин, отнятых у них на основании этого указа». // Законодательные акты русского государства второй половины XVI — первой половины XVII века. Тексты / Под ред. Н. Е. Носова. Л.: «Наука», 1986. 265 с.

16. Устав князя Ярослава Владимировича «0 церковных судах». Пространная редакция // Российское законодательство X-XX веков в 9 томах. Т. 1 / Под ред. О. И. Чистякова. М.: Изд.: Юрид. Лит, 1984. 432 с.

(c) Сайфуллина Надежда Алимбаевна (n.a.sajfullina@utmn.ru ),

Головнин Владимир Николаевич ( v.n.golovnin@utmn.ru ), Савина Наталья Сергеевна ( nat-992011@mail.ru).

Журнал «Современная наука: актуальные проблемы теории и практики» 